system, although the Vicnna decisions appeared to make intornational world standardization now impossible. Wo had to consider the potentiality of development quality later on ns belween all three systems. He could not now give a date when colour television would be available in Britain.

\section{Radio Regions}

In view of the emphnsis on regionalism in recent parliamentary debates in the House of Commons concerning broadcasting, the lecture deliverod by Mr. H. Davies on the "Role of the Regions in British Broadeasting" at the fourth of the third series of lunch-time lectures in the Concert Hall at Broadcasting House (now issued in the BBC Lunch-time Locture series) is of particular intercst. After reviewing the origins of regionalism he points out that, while the regions into which the United Kingdom has boon historically divided remain satisfactory only where there are common bonds of interest the characters of which coincide in the region, whether othnic, social or cultural, the development of VHF radio and the establish. ment of television ncws-interview studios in sub-rogional centres brought fresh opportunities in the English regions which wero eagerly and enterprisingly welcomed. $\mathrm{He}$ found enthusiastic support in all the regions for the further devolopment of a now system of local broadcasting by sotting up small stations in cities, towns and other natural communities, but ho insists that regional centres must be more than studios of convenience. The fundamental obligations of a region ho regards as being towards its community rather than towards its central organization, but the community in turn has its obligations towards tho medium. Regional broadeasting needs eonstantly to remind itsolf that, although it is itsolf a minority exercise, the final answer does not lie in a conglomeration of minority excrcises; the regional producer, despite selectivity, must be versatilo, and the exerciso of judgmont and flair are the most important functions he performs. Moreover, one way or another, a region must rolate itself to the metropolis and a proper relation betwcen London and the regions is of vital importance. A centre serionsly and positively concerned with the regional studios, dofining the rich and separate identities of the people of Britain, had a most exciting opportunity to demonstrate that the whole is the sum of the parts.

\section{Organization for Economic Co-operation and Development}

THE existence of the Organization for Economic Co-operation and Development is well known, but probably relatively fow poople really appreciate the scope of international activities and ramifications of the constructive work undertaken by this important body. Twenty-one countries are represented in the Organization: Austria, Bolgium, Canada, Denmark, France, Gormany, Greece, Tceland, Ireland, Italy, Japan, Luxembourg, the Netherlands, Norway, Portugal, Spain, Sweden, Switzorland, Turkey, the United Kingdom and tho United States. An exarnple of the kind of project sponsored by the Organization is the Consortium for Turkey which ". . Was formed in the summer of 1962 to provide assistance for the long-term cconomic development of Turkey. It is a de facto association of Momber countries who are prepared to make a contribution to the l'urkish Development Prograrnme". Some encouraging mensure of success has alroady been realized in pursuance of this schems, of which details are given in the bi-monthly publication OEOD (Observer (No. 15; April 1965. ().E.C.T) Information Servien, Chn̂tenu de la Muette, Paris 16e), From this periodical, published in Finglish and French much information on the important economic and political significanee of tho work of the Organization in conntries of the Western world may be readily obtained. In this
April issue, besides the aceount of the Consortium for Turkey, the subjects discussed are: relating seience and technology to economic development (a five-country experiment); publicity for pharmaceutical products (regulations that hamper trade); present-day problems and policies; the improvement of agricultural market information (colloction and collation of forecasting data for Government use); some aspects of cotton industry problems; vocational training for adults (an answor to the demand for skilled manpower); and pilot experiments in internationol scientific $\%$-operation (international contres for research oriented on natural resources). 'This magazine is well produced and illustrated. Its perusal will at least impress the reader with the fact that the Organization for Economic Co-operation and Development is a truly live body, steadily but surely achicving the ideals for which it was originally founded.

\section{The Great Society: a Plan}

Under the title The Great Society : a Plan (Pp. 36. London: United States Information Service, Amorican Embassy, 1965)-to which W. Lippman contributes an introduction, "The Principle of the great Society", $\mathrm{cx}$ plaining President Johnson's use of the words "the Great Society" - arc collected excerpts from I'resident Johnson's message to Congress on the State of tho Union (January 4); his messages to Congress on the American economy (January 28); on the Budget for 1966 (January 25); the Defence Budget (January 18); foreign aid (January 14); health (January 7); education (January 12); immigration (January 13); and his inaugural address of January 20). A fow facts recorded may be noted here. Proposed expenditure on space research and tcchnology in 1966 is 5,100 million dollars, on natural resources 3,900 million dollars, and on education 2,700 million dollars. More than 6,000 million dollars a year is being invested in military research and development. For technical co-operation, expenditure of 210 million dollars is proposed, with a further 155 million dollars in contributions to international organizations.

\section{Designing the Controls of Machines}

To the workex in the old days tools were extensions of his arms. They had been adapted by centuries of uso. The levers, knobs and switches of modern equipment cannot evolve in this way. They must be designed deliberatcly to fit human caprcity. In Men, Machines and Controls, K. A. Provins, reader in psychology at tho University of Adelaide, gives an interesting account of how human factors have to be considered in the design of machine controls (Ergonomics for Industry, No. 7: Men, Machines and Controls. K. A. Provins. I'p. 24. London: D.S.I.R. Obtainable from Warren Spring Laboratory, Stevenage, Herts. 1965. (tratis). The range of movement of the different parts of the body affects the placing of controls; and the height, weight, uge and sex of tho operntor influence their detailed design. Surprisingly, nationality plays a part. Difforence in physiqun between races aro important when designing for export. For example, in sorne parts of the world, the majority of people could not roach tho control pedals of agricultural tractors made for the English furmers. Different parts of the body have different eapacities for exerting force and for accurale movement, so the function of a control on a machine will often determino its position relative to an operator. Controls may be classified in terms of the foree, speed and aceuracy needed to operate them. The amount of force that an operator can exert with a given limb will vary with his posture and with how long he hes to maintain the force. Accuracy will depend on the charactoristics of the control and the way in which information about the task is for back to the oporator, as well as on his personal characteristics. Spend and range of movement depond 